\title{
Rzetelność źródeł informacji a trafność treści nauczania w planowaniu kursu języka obcego dla potrzeb zawodowych
}

\author{
Reliability of information sources and relevance of teaching content in planning a foreign language \\ course for professional needs
}

\author{
Magdalena SOWA \\ Uniwersytet Marii Curie-Skłodowskiej/ Maria Curie-Skłodowska University \\ E-mail: magdalena.sowa@umcs.pl,
}

\begin{abstract}
Changes in the contemporary world affect the evolution of the foreign language teacher profession, its role and the required competences. In addition to his/her traditional teaching activity, the foreign language teacher must often undertake pre-learning tasks such as designing the curriculum, developing teaching techniques and didactic materials. This is illustrated particularly well with the example of a specialist language teacher. Hence, it is necessary to modify and/or redefine the curricula of language teacher training (including LSP teachers). The aim of the present paper is to reflect on the current role of an LSP teacher and his/her competencies required in the needs analysis process for developing a language training program for professional purposes. Starting from the needs analysis, we will consider the tasks specific for the activity of an LSP teacher and the sources of information which he/she should explore in order to design the curriculum content. We base the present reflection on our professional experience in training French language teachers in Poland.
\end{abstract}

Keywords: LSP, LSP teacher, LSP curriculum design, teacher training, sources of information

\section{Wstęp}

Widoczna w ostatnich latach profesjonalizacja kształcenia językowego (także na kierunkach filologicznych) ukierunkowuje wyraźnie proces kształcenia na konkretne umiejętności wymagane i/ lub pożądane w środowisku zawodowym. Uczący się języków obcych pragną je opanować w celu ich praktycznego wykorzystania w przyszłej pracy zawodowej, czyniąc z języków obcych klucz do sukcesu na rynku zatrudnienia. Nie omijając $w$ żadnym stopniu kształcenia językowego, profesjonalizacja obiera za cel doprowadzenie uczących się do nabycia i/ lub rozwinięcia kompetencji komunikacyjnej w języku obcym w takim stopniu, aby byli oni w stanie, przy jego pomocy, realizować zadania zawodowe w miejscu pracy. Innymi słowy, uczący winni posługiwać się językiem obcym zgodnie z zasadami poprawności językowej, ale także z poszanowaniem zasad i konwencji obowiązujących w danej społeczności zawodowej, dzięki czemu będą mogli być zaliczeni do takiego czy innego grona profesjonalistów. Aby proces kształcenia językowego mógł pozwolić na wykształcenie kompetentnego użytkownika języka obcego, niezbędny jest w nim udział profesjonalistów i/ lub specjalistów, którzy właściwie opracują i zrealizują program nauczania języka. Pojęcie ,profesjonalisty” lub „specjalisty do spraw języka” coraz częściej odnoszone jest do nauczyciela języka specjalistycznego (zob. J.-J. Richer 2012). 
Celem niniejszego tekstu jest refleksja nad kształceniem nauczycieli języków specjalistycznych przez pryzmat wybranych elementów planowania kursów językowych dla potrzeb zawodowych. Owe elementy pozwalają wskazać na rodzaj źródeł informacji wykorzystanych do opracowania koncepcji programu nauczania pożądanej dla odbiorcy i zleceniodawcy oraz zgodnej z regułami komunikacji w docelowym obszarze zawodowym. Kwestią kluczową w podjętej refleksji będzie zatem (samo)ocena działań nauczyciela w zakresie doboru źródeł informacji, ich obiektywności i wiarygodności, co ukazane zostanie na przykładzie eksperymentu badawczego przeprowadzonego na grupie studentów filologii romańskiej przygotowujących się do wykonywania zawodu nauczyciela języka francuskiego (także dla potrzeb zawodowych) na studiach drugiego stopnia. Zaprezentowana $\mathrm{w}$ tekście analiza ankiet przeprowadzonych wśród w/w informatorów pozwoli, mamy nadzieję, na finalny osąd rzetelności i jakości projektowanego przez nich kształcenia specjalistycznego i poziomu satysfakcji jego potencjalnych odbiorców/ uczestników.

\section{Nauczyciel języka specjalistycznego jako profesjonalista}

Jakość pracy i skuteczność działań nauczyciela może być oceniana w podobny sposób, jak ma to miejsce w sferze funkcjonowania przedsiębiorstw. Profesjonalny nauczyciel języka specjalistycznego - tak jak każdy inny profesjonalista - to osoba, która potrafi samodzielnie inicjować i realizować działania adekwatnie do potrzeb miejsca, osób i czasu, nie ograniczając się wyłącznie do wykonywania (odgórnie) formułowanych zaleceń czy bezrefleksyjnego realizowania rutynowych działań (G. Le Boterf 2009: 23). Profesjonalista - a więc także i nauczyciel - to osoba, której można zaufać: dołoży on bowiem wszelkich starań, by wykorzystać dostępne sobie zasoby i wypracować rozwiązania stosowne do zidentyfikowanych sytuacji problemowych, nie zaniedbując przy tym niczego istotnego (G. Le Boterf 2009: 244). W zależności od profilu zawodowego odbiorców i/ lub zleceniodawców kształcenia, jak również uwarunkowań sytuacyjnych, nauczyciel języka specjalistycznego staje przed koniecznością opracowania celowej, skrojonej na miarę, mniej lub bardziej specjalistycznej, a niejednokrotnie także jednorazowej koncepcji kształcenia w oparciu o rzetelnie przeprowadzą analizę potrzeb oraz dogłębne rozpoznanie obszaru zawodowego, w którym nie (zawsze) jest specjalistą. O profesjonalizmie nauczyciela zaświadcza także jego umiejętność łączenia słowa $\mathrm{z}$ działaniem, pracy indywidualnej z zespołową, własnej kreatywności z tym, co metodycznie pożądane, samodzielności z zależnością od parametrów sytuacyjnych (J.-J. Richer 2012: 164).

Wynika z powyższego, że profesjonalizm nauczyciela polega na operacyjnym wykorzystaniu kompetencji, którymi dysponuje, aby programowany i/ lub realizowany przez niego proces kształcenia zakończył się sukcesem dydaktycznym. Powodzenie tego ostatniego jest warunkowane aktywizacją przynajmniej trzech rodzajów kompetencji w zakresie języka obcego, glottodydaktyki i wiedzy dyscyplinarnej. Dobrej znajomości nauczanego języka obcego muszą towarzyszyć umiejętności w zakresie tworzenia i prowadzenia zajęć językowych z poszanowaniem reguł dydaktyki języków specjalistycznych. Do tego zestawu kompetencji dodać także należy minimalną choćby znajomość obszaru zawodowego i wiedzy na temat funkcjonowania w nim 
JOS (E. Gajewska/ M. Sowa 2014). Wskazane powyżej kompetencje dochodzą do głosu w trakcie realizacji wielu zadań pozwalających określić różnorodność i złożoność ról, jakie nauczyciel języka specjalistycznego może pełnić na różnych etapach procesu dydaktycznego. Nie ulega wątpliwości, że nauczyciel języka jest dla uczących się specjalistą w zakresie nauczanego języka obcego. Bez względu na dziedzinę, której dotyczy nauczany język (medycyna, elektronika, prawo itp.), nauczyciel JS jest, jak by nie było, przede wszystkim nauczycielem języka, który - w odróżnieniu od specjalisty danej dyscypliny (lekarza, elektronika, prawnika itp.) - potrafi właściwie nauczyć tych elementów języka, które pozwalają poprawnie zrozumieć treści specjalistyczne i praktyki werbalne realizowane za pomocą języka w konkretnym środowisku zawodowym (zob. J.-M. Mangiante/ C. Parpette 2004, T. Dudley-Evans/ M.St. John 1998).

Nauczenie w/w elementów języka pozwalających na zrozumienie specjalistycznych treści oraz praktyk werbalnych właściwych dla zawodu, stanowiska czy, szerzej, wspólnoty zawodowej zmusza nauczyciela do wyjścia poza własną strefę komfortu i wykorzystania dostępnych zasobów informacyjnych. Te ostatnie pozwolą mu trafnie zdiagnozować potrzeby uczących się i mniej lub bardziej dogłębnie poznać docelowy obszar zawodowy, właściwie wyłuskać z niego elementy pożądane pod kątem potrzeb, celów i treści projektowanego kształcenia oraz logicznie i optymalnie wkomponować je w ramy organizacyjne planowanego kursu. Stworzenie odpowiedniego sylabusa i/ lub programu kształcenia, jak również dostarczenie poprawnie skomponowanych materiałów dydaktycznych wymagają współpracy z innymi, prowadzenia własnych poszukiwań i badań. Aktywność badawcza nauczyciela języka specjalistycznego ma tu rangę porównywalną z aktywnością dydaktyczną (D.R. Hall 2013, H. Basturkmen 2014) i przejawia się w formie pogłębionej analizy obszaru zawodowego i właściwych dla niego sytuacji komunikacyjnych, potrzeb odbiorców kształcenia, materiałów źródłowych w postaci tekstów i dyskursów itp.

Wreszcie nie można zapominać o roli nauczyciela jako ewaluatora, który, na różnych etapach swojej pracy, ocenia materiały nauczania, zrealizowane zajęcia czy też postępy w nauce swoich uczniów (T. Dudley-Evans/ M.St. John 1998, D. Belcher 2006). Jako refleksyjny praktyk analizujący dostępne sobie zasoby i nie zaniedbujący niczego istotnego winien także ocenie poddać jakość i skuteczność własnych działań angażowanych na rzecz tworzenia i realizacji kursu językowego dla potrzeb zawodowych.

\section{Profesjonalizm nauczyciela a planowanie kursu języka specjalistycznego}

Profesjonalizm nauczyciela poddany jest próbie na każdym etapie jego pracy, tj. przed rozpoczęciem kształcenia, w trakcie jego realizacji i po jego zakończeniu. Niemniej jednak planowanie kursu języka specjalistycznego jest tym etapem, na którym szczególnie uwidaczniają się starania nauczyciela $\mathrm{w}$ zakresie identyfikacji dostępnych mu źródeł i ich operacyjnego wykorzystania, jak również wypracowania rozwiązań stosownych do zaobserwowanych problemów. Kompleksowość modelu planowania 
kursu języka specjalistycznego ${ }^{1}$ i wzajemna zależność poszczególnych jego etapów pokazują dobitnie, jak dużą rolę w pracy nauczyciela odgrywa umiejętność prowadzenia szeroko zakrojonej analizy (m.in. w zakresie motywów i potrzeb beneficjentów kursu, specyfiki obszaru zawodowego i tych jego elementów, które winny zostać uwzględnione w programie nauczania, wyboru dostępnych źródeł informacji oraz zebranych na ich podstawie danych, właściwości ćwiczeń dydaktycznych w odniesieniu do zdiagnozowanych potrzeb itp.), która jest podstawą trafności wyborów dokonywanych w ramach kolejnych faz programowania kształcenia.

Nawet szablonowo sporządzony plan pracy nauczyciela na etapie programowania kursu języka specjalistycznego pozwala opracować ogólną koncepcję kształcenia, odnosząc ją do takich parametrów jak odbiorca (kto?), cel (dlaczego i po co?), treść (co?), czas i miejsce (kiedy i gdzie?). Identyfikacja powyższych parametrów jest pochodną informacji na temat potrzeb uczestników kształcenia, wymagań zamawiającego/ oferującego kurs oraz specyfiki komunikacji zawodowej i przyjętych w niej norm, jakie nauczyciel na wstępie zgromadzi, a następnie podda rzetelnej i obiektywnej analizie. Solidna diagnoza potrzeb prowadzi do poprawnego zdefiniowania celów i treści kształcenia oraz właściwego doboru technik nauczania, a jej naturalną konsekwencją są trafne kryteria ewaluacji i wysoka skuteczność procesu dydaktycznego. Dlatego też ważne jest, aby, planując program nauczania języka dla potrzeb zawodowych, nauczyciel potrafit:

- zidentyfikować i zlokalizować właściwe źródła informacji, tzn. wiedział, gdzie szukać informacji i kogo o nie pytać/ prosić;

- dokonać efektywnej eksploracji źródeł informacji, do których ma lub może mieć dostęp, tzn. umiał określić właściwe kryteria selekcji i poprawnie zastosować je w praktycznym działaniu;

- optymalnie wykorzystać dostępne źródła informacji, rozpoznając w nich właściwie elementy (językowe, zawodowe, kulturowe itp.) pożądane w odniesieniu do planowanego kursu.

Planistyczne działania nauczyciela i poszukiwanie odpowiedzi na kluczowe dla ich realizacji pytania winny skłaniać nauczyciela-twórcę kursu do konfrontowania, w miarę możliwości, swoich decyzji i wyborów z otoczeniem zewnętrznym, tj. zleceniodawcami i/ lub zleceniobiorcami programowanego kursu oraz z zasobami informacyjnymi w terenie, które wyznaczą zakres i prawidłowość treści będących przedmiotem kształcenia. W tym kontekście uzasadnionym wydaje się twierdzenie, że w procesie planowania procesu dydaktycznego bardzo istotne są kompetencje informacyjne nauczyciela, które polegają: i) na pozyskiwaniu informacji w odniesieniu do

\footnotetext{
${ }^{1}$ Wzorując się na modelu planowania kursu języka francuskiego dla potrzeb zawodowych opracowanego przez J.-M. Mangiante i C. Parpette (2004), uznajemy, że może on być z powodzeniem zastosowany do kursu jakiegokolwiek języka obcego. Struktura modelu obejmuje pięć głównych etapów, tj. analiza zapotrzebowania, analiza potrzeb, pozyskanie danych źródłowych, analiza zebranych danych, opracowanie ćwiczeń, na które z kolei składają się wielorakie zadania szczegółowe polegające na gromadzeniu i przetwarzaniu informacji przez nauczyciela przez pryzmat kryteriów istotnych dla tworzonego kursu.
} 
własnych potrzeb informacyjnych, ii) na analitycznej ocenie tych informacji pod kątem ich zasadności i użyteczności warunkującej właściwą ich selekcję, iii) a także na poprawnym zastosowaniu zdobytych i stosownych informacji w praktyce. Przenosząc powyższe składowe tak zdefiniowanej kompetencji informacyjnej do sylwetki nauczyciela-profesjonalisty, który dokłada wszelkich starań, aby wykorzystać dostępne sobie zasoby i na ich podstawie wypracować stosowne rozwiązania, można stwierdzić, że jego umiejętności w zakresie pozyskiwania, oceny i wykorzystania informacji będą zasadniczo dotyczyć:

- określenia źródeł informacji z trafnym rozpoznaniem, które z nich są dla niego realnie dostępne (a które tylko potencjalne), a co za tym idzie, obiektywnie zdecydować, które ze źródeł dostępnych powinien i/ lub musi wykorzystać względem wymagań projektowanego kursu;

- znajomości technik i narzędzi pozyskiwania informacji z obszaru zawodowego, którego języka będzie nauczał, takich jak m.in. obserwacje, wywiady, ankiety, sondaże, zapytania, literatura fachowa, dokumenty autentyczne itp.;

- dywersyfikacji źródeł informacji, która pozwoli mu na pozyskanie różnorodnego materiału informacyjnego;

- triangulacji metod i narzędzi pozyskiwania i oceny informacji, co pozwala zwiększyć ich rzetelność, obiektywność, użyteczność, a tym samym ułatwia ich wybór i wykorzystanie w praktyce.

Należy jednak podkreślić, że operacyjne wykorzystanie zasobów informacyjnych dokonuje się na podstawie świadomej oceny nauczyciela w zakresie tego, co sam wie/ chce/ potrafi/ powinien/ może zrobić, a tego, na co pozwala i w czym mu „pomaga" kontekst zewnętrzny, w którym jego planistyczne działania są realizowane. Wiarygodne, rzetelne i obiektywne źródła pozwolą na pozyskanie adekwatnych i funkcjonalnych informacji na temat obszaru zawodowego i specyfiki jego komunikacji językowej, nadając tym samym właściwy cel planistycznym działaniom nauczyciela oraz działaniom uczących się, tak w trakcie nauki, jak i w docelowym obszarze zawodowym. W naszym przekonaniu optymalne rozpoznanie potencjału sytuacji właściwej nauczycielowi w danym miejscu i czasie oraz ocena możliwości własnego działania w tejże sytuacji to umiejętność przydatna i pożądana, którą należy kształtować, także w kontekście przygotowania do zawodu nauczyciela języka obcego, a szczególnie języka dla potrzeb zawodowych.

\section{Nauczyciel języka specjalistycznego i jego profesjonalne kompetencje informacyjne: analiza przypadku}

Każda osoba aktywnie zaangażowana w proces nauczania staje w obliczu pytania co do wyboru właściwego podejścia dydaktycznego: ,[c]zy kształcić młodych za pomocą podejścia teoretycznego, które pozwoli na rozwinięcie ich zdolności rozumowania i logiki, czy też, najwcześniej jak to możliwe, konfrontować ich z sytuacjami życia praktycznego, (...) aby uczynić ich zdolnymi do działania, kiedy przyjdzie im realnie mierzyć się z powierzonymi obowiązkami” (D. Lehmann 1996: 147, tłum.: M. S.). W obliczu podobnego dylematu stają także twórcy programów przygotowujących 
do wykonywania zawodu nauczyciela oraz nauczyciele kształcący przyszłych nauczycieli języków obcych dla potrzeb zawodowych. Sytuacja tych ostatnich jest trudna, bowiem zajęcia z dydaktyki języków obcych dla potrzeb zawodowych rzadko zajmują miejsce w uniwersyteckich programach kształcenia nauczycieli w Polsce, choć szczęśliwie się zdarzają, co przedstawimy w dalszej części niniejszego tekstu.

Tzw. standardy kształcenia nauczycieli ${ }^{2}$ dla trzeciego i czwartego etapu edukacyjnego, zakładają przygotowanie do pracy nauczyciela języka obcego we wszystkich typach szkół i placówek oświatowych. Oznacza to, że programy kształcenia nauczycieli na studiach magisterskich, poza nauczaniem języka ogólnego w gimnazjach czy liceach ${ }^{3}$, także powinny uwzględniać specyfikę nauczania w szkołach zawodowych/ branżowych i przygotowywać do nauczania obowiązkowego $\mathrm{w}$ ich programach szkolnych przedmiotu „Język obcy ukierunkowany zawodowo" (JOZ). W oparciu o takie właśnie przekonanie włączono do programu zawodowego kształcenia nauczycieli na kierunku filologia romańska zajęcia z dydaktyki języka francuskiego dla potrzeb zawodowych, które realizowane były na studiach drugiego stopnia w Instytucie Filologii Romańskiej Katolickiego Uniwersytetu Lubelskiego. Doświadczenie i refleksja płynące z realizacji w/w zajęć w cyklu 2015-2017 są przedmiotem szczegółowej analizy prezentowanej w dalszych częściach niniejszego tekstu.

\subsection{Kontekst i warunki kształcenia przygotowującego do nauczania języka francuskiego dla potrzeb zawodowych}

Przygotowanie do nauczania języka francuskiego dla potrzeb zawodowych zostało umieszczone w programie studiów drugiego stopnia na drugim roku w trzecim semestrze studiów i realizowane w ramach przedmiotu „Dydaktyka języka francuskiego dla potrzeb zawodowych". Przedmiotowe zajęcia kończyły blok przygotowania metodycznego do nauczania pierwszego języka (język francuski) realizowany na studiach magisterskich i obejmujący także dydaktykę szczegółową języka francuskiego w placówkach ogólnokształcących (gimnazjum i liceum). Biorąc pod uwagę 30-godzinny wymiar zajęć zarezerwowanych dla dydaktyki specjalistycznej stosowne jest raczej traktować w/w ćwiczenia bardziej jako wprowadzenie do nauczania języka zawodowego niż rzetelne do niego przygotowanie.

Nie zaniedbując teoretycznych aspektów nauczania języka dla potrzeb zawodowych, główny nacisk został jednak położony na ćwiczenie umiejętności praktycznych i konfrontację z realnymi zadaniami, jakie należy wykonać przy programowaniu

\footnotetext{
${ }^{2}$ Rozporządzenie MNiSW z dn. 17 stycznia 2012 r. w sprawie standardów kształcenia przygotowującego do wykonywania zawodu nauczyciela (Dz.U. Poz. 131).

${ }^{3}$ W rozporządzeniu z 2012 r. wskazano cztery etapy edukacyjne: etap I - edukacja wczesnoszkolna (klasy I-III szkoły podstawowej), etap II - szkoła podstawowa, etap III i IV - gimnazjum, szkoła ponadgimnazjalna i kształcenie w zawodzie. Reforma polskiego systemu oświaty wprowadzona w roku szkolnym 2017/18 likwidująca gimnazja i wprowadzająca 8-klasową szkołę podstawową, 4-letnie liceum oraz 5-letnie technikum, nie pociągnęła za sobą zmiany wytycznych w zakresie kształcenia nauczycieli. W chwili redakcji niniejszej publikacji obowiązują standardy i etapy kształcenia wskazane w rozporządzeniu z 2012 r.
} 
kursu języka specjalistycznego. Stąd też uczestnicy 12-osobowej grupy zainteresowanych wykonywaniem w przyszłości zawodu nauczyciela języka francuskiego zostali poproszeni o opracowanie dość ogólnej koncepcji kursu języka francuskiego dla wybranej grupy zawodowej ${ }^{4}$. Wspomniana koncepcja zakładała dość precyzyjne:

- określenie odbiorców kształcenia poprzez zdefiniowanie grupy docelowej i zidentyfikowanie jej profilu zawodowego: na czym polega wybrany zawód/ stanowisko? wykonywanie jakich obowiązków zawodowych zakłada?

- zdiagnozowanie jej potrzeb w odniesieniu do nauki języka francuskiego: jakie obowiązki są wykonywane w języku obcym/ francuskim? w jakich sytuacjach komunikacyjnych są osadzone? realizacji jakich zadań językowych wymagają?

- zdefiniowania celów nauczania: czego nauczyć i po co w zakresie języka, kultury i/ lub zawodu?

- wyselekcjonowanie treści nauczania na podstawie analizy właściwych materiałów źródłowych ilustrujących specyfikę komunikacji w wybranym obszarze zawodowym.

Samodzielna realizacja tego praktycznego i realnego zadania była poprzedzona teoretycznym omówieniem na zajęciach wskazanych aspektów i analizą przykładowych rozwiązań metodycznych dla języka francuskiego różnych branż.

Podstawowym celem projektu było przygotowanie przez studentów zarysu kursu języka francuskiego dla potrzeb zawodowych dla dowolnie wybranej grupy zawodowej, realizując stopniowo cele pośrednie zdefiniowane powyżej. Opracowane przez studentów finalne programy kursów zawierały jednak szereg uchybień (m.in. powierzchowny opis zawodu/ stanowiska, nieadekwatne dokumenty autentyczne, błędne formy językowe w zakresie aktów mowy itp.), które nasunęły wątpliwości co do rzetelności oraz wiarygodności wykorzystanych przez nich źródeł informacji w zakresie diagnozy potrzeb grupy docelowej i wymagań komunikacji specjalistycznej właściwej dla wybranego kontekstu pracy. Aby ustalić przyczynę powyższych nieprawidłowości uznano za niezbędne skierowanie do studentów-autorów prac ankiety samooceny ich własnej pracy, która pozwoliłaby uzyskać bardziej szczegółowe informacje na temat źródeł informacji, jakimi studenci posiłkowali się w trakcie własnej pracy (skąd czerpali informacje na poszczególnych etapach własnej pracy planistycznej?) oraz oceny jakości i stopnia przydatności zawartych w nich informacji względem projektowanego kursu (które źródła informacji były dla nich najważniejsze/ najbardziej użyteczne?). Skonstruowana na potrzeby samooceny ankieta zawierała siedem szczegółowych pytań odnoszących się do poszczególnych etapów wykonywanej pracy $\mathrm{w}$ zakresie planowania i przygotowania matrycy kursu. Pytania zawarte $\mathrm{w}$ ankiecie miały na celu uzyskanie informacji na temat wykorzystanych źródeł informacji na etapach dotyczących:

- wyboru i opisu branży/zawodu/ stanowiska;

- opisu sytuacji komunikacyjnych i realizowanych w nich zadań językowych;

${ }^{4}$ Projekty realizowane były w grupach 3-4 osobowych, a ich autorzy mogli dowolnie zdecydować o profilu zawodowym swoich potencjalnych docelowych odbiorców kształcenia (branża/ zawód/ stanowisko). 
- określenia celów komunikacyjnych i językowych dla planowanego kursu;

- selekcji dokumentów autentycznych;

- zdefiniowania aktów mowy realizowanych w odnośnym kontekście pracy5.

Aby precyzyjnie ustalić rodzaj wykorzystanych źródeł informacji, w ankiecie zaproponowano listę przykładowych odpowiedzi w zakresie zasobów informacyjnych potencjalnie użytecznych ${ }^{6}$ do wykonania zleconej pracy. Do każdej z propozycji odpowiedzi została dodana pięciostopniowa skala wartości ${ }^{7}$, która pozwoliła wskazać rolę, jaką studenci przypisali danemu źródłu pod względem jego ważności i stopnia wykorzystania w ramach własnej pracy.

\subsection{Rodzaj i wartość źródel informacji wykorzystanych do programowania kształcenia: analiza danych}

Jak stwierdzono powyżej, studentom pracującym nad projektami kursów języka zawodowego pozwolono na wolny wybór branży/ stanowiska/ zawodu. Biorąc pod uwagę różnorodność ich preferencji, uznano za interesujące poznanie powodów, jakimi studenci się kierowali w swoich decyzjach. Odpowiedzi na pytanie ankietowe, jakie zostały przez nich udzielone dowodzą, że, z wyjątkiem jednej osoby, wszyscy studenci wybrali obszary zawodowe, które są im znane na podstawie ich doświadczenia życiowego ( 7 osób), zawodowego ${ }^{8}$ ( 2 osoby) lub informacji uzyskanych na zajęciach ( 2 osoby). Wybór grupy docelowej opracowywanego kursu był także podyktowany takimi kryteriami jak łatwość opisu danego zawodu/ stanowiska (7 osób), dobra znajomość obszaru zawodowego (3 osoby), dogodny dostęp do informacji źródłowych (4 osoby).

Wskazane powyżej odpowiedzi dają już w pewnej mierze wyobrażenie potencjalnych źródeł informacji, które mogły być wykorzystane przez studentów w trakcie ich pracy. Niemniej jednak interesujące będzie ich dokładne przeanalizowanie szczególnie pod kątem stopnia ich przydatności względem wykonanego projektu.

\subsubsection{Opis profilu zawodowego grupy docelowej}

Opis docelowego zawodu pozwala zrozumieć specyfikę profesji, jej logikę i rolę

\footnotetext{
${ }^{5}$ Każde z pytań ankiety zostało skonstruowane w następujący sposób: „Opis zawodu wykonałem/am na podstawie...”, „Opis sytuacji komunikacyjnych i właściwych dla nich zadań zawodowych wykonałem/am na podstawie..." itd.

${ }^{6}$ Zaproponowana lista zawierała następujące propozycje odpowiedzi: własna intuicja i doświadczenie życiowe, moja wiedza i doświadczenie zawodowe, analiza materiałów dostępnych w Internecie, informacje z zajęć na uniwersytecie, informacje od osób wykonujących dany zawód, analiza literatury fachowej, analiza podręczników do nauki języka zawodowego i/lub ogólnego, obserwacja działań pracowników w autentycznym miejscu pracy, rejestracja (audio/wideo) działań pracowników w ich miejscu pracy, inne (jakie?).

${ }^{7}$ Poszczególnym przedziałom zaproponowanej skali 0-4 przypisano następujące wartości: 0 nieważne, 1 - mało ważne, 2 - średnio ważne, 3 - ważne, 4 - bardzo ważne.

${ }^{8}$ Należy podkreślić, że duża liczba studentów uczestniczących w zajęciach miała za sobą doświadczenie zawodowe w postaci odbytych stażów w przedsiębiorstwach lub była aktualnie zatrudniona na umowę o pracę $\mathrm{w}$ firmach informatycznych.
} 
w szerszym kontekście pracy. Uwzględnienie tych elementów wpływa na całościową koncepcję kursu, ponieważ jego twórca poszukuje obiektywnych kryteriów definiujących z jednej strony kompetencje wymagane przez środowisko zawodowe, a z drugiej efekty kształcenia pożądane do osiągnięcia po zakończeniu kursu. Pośród źródeł informacji najczęściej eksploatowanych na tym etapie planowania programu nauczania w pierwszej kolejności pojawiają się intuicja i życiowe doświadczenie studentów, które ci ostatni starają się zobiektywizować za pomocą źródeł dostępnych w Internecie. W dalszej kolejności wymieniane są informacje uzyskane na zajęciach uniwersyteckich. Źródła informacji bardziej bezpośrednio zakorzenione w kontekście zawodowym, takie jak konsultacje ze specjalistami czy analiza dostępnej literatury fachowej występują wśród zasobów cieszących się najmniejszą popularnością wśród studentów.

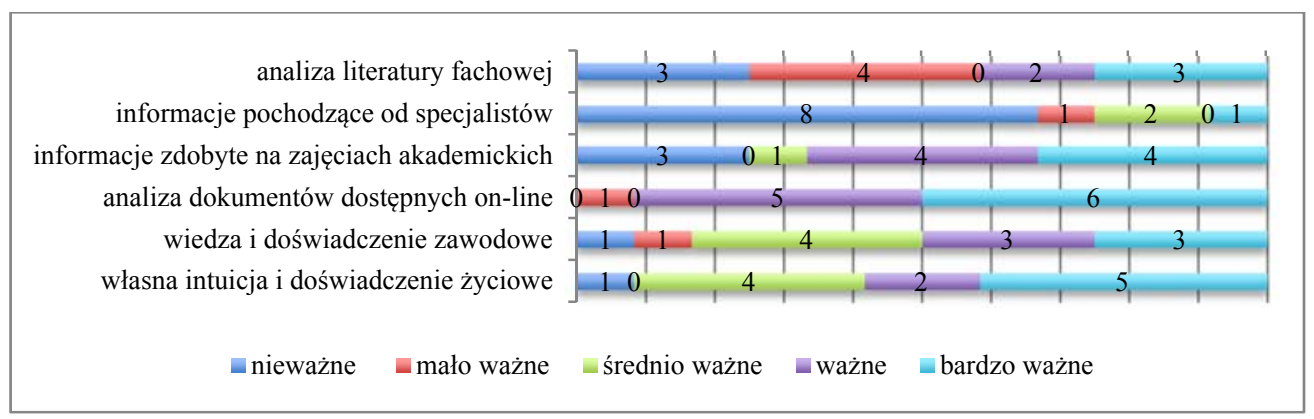

Wykres 1. Zasoby informacyjne wykorzystane do opisu profilu zawodowego grupy docelowej

\subsubsection{Identyfikacja sytuacji komunikacyjnych i zadań zawodowych}

Każda osoba wykonująca jakiś zawód uczestniczy w różnych sytuacjach komunikacyjnych, w ramach których wykonuje liczne zadania o charakterze językowym i pozajęzykowym ${ }^{9}$. Kolejny etap pracy studentów polegał więc na identyfikacji podobnych informacji w odniesieniu do wybranego przez nich zawodu/ stanowiska, dla którego planowali kurs języka specjalistycznego. Podobnie jak na etapie wcześniejszym, priorytetowymi źródłami informacji były intuicja i doświadczenie życiowe oraz Internet. Częściowo studenci oparli swoje wybory na własnym doświadczeniu zawodowym oraz obserwacji docelowego obszaru zawodowego. Niemniej jednak najrzadziej sięgali po informacje pozyskane drogą rejestracji zachowań pracowników w ich środowisku pracy, wywiadów ze specjalistami czy analizy dostępnych podręczników do nauczania języka zawodowego.

\footnotetext{
${ }^{9}$ Tak np. podczas sytuacji komunikacyjnej właściwej dla wizyty lekarskiej lekarz wykonuje takie zadania, jak m.in. osłuchanie pacjenta, postawienie diagnozy, wypisanie recepty, sformułowanie zaleceń w odniesieniu do zalecanego leczenia itp.
} 


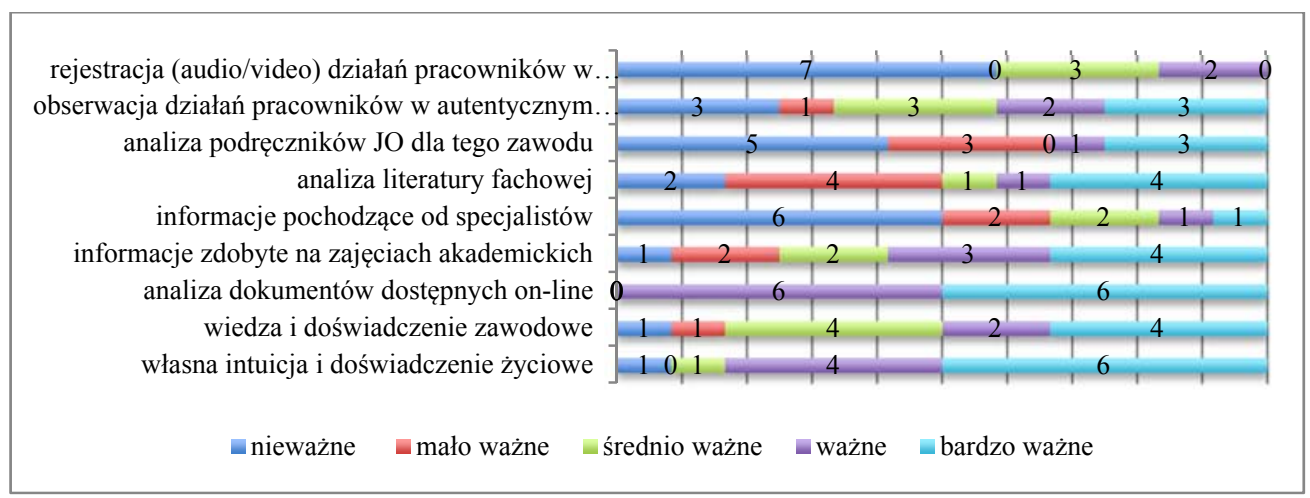

Wykres 2. Zasoby informacyjne wykorzystane do opisu sytuacji komunikacyjnych i zadań zawodowych

\subsubsection{Definiowanie celów ksztalcenia}

Analiza sytuacji komunikacyjnych i osadzonych w nich zadań prowadzi bezpośrednio do określenia elementów językowych niezbędnych do wykonywania działań zawodowych. Językowy wymiar aktywności zawodowej wskazuje na treści nauczania, które należy uwzględnić w planowanym programie kształcenia. Elementy języka wyłuskane na podstawie analizy działań zawodowych wykonywanych przez pracowników stają się w sposób naturalny operacyjnymi celami kształcenia, wskazując na rodzaj wiedzy i umiejętności, jakie uczący winni przyswoić sobie w trakcie kursu, w którym mają aktywnie uczestniczyć. Wybór źródeł informacji wykorzystanych na tym etapie pracy dokonuje się zasadniczo w obrębie tych samych zasobów co wcześniej. Dominują w sposób zdecydowany informacje określone w sposób intuicyjny lub na podstawie Internetu i/ lub zajęć akademickich. Mniej popularne są źródła wymagające większego zaangażowania ze strony studentów, takie jak m.in. nagrania specjalistów w ich miejscu pracy czy wywiady z nimi. W porównaniu do poprzednich etapów planowania zauważyć należy jednak wzrost zainteresowania studentów zasobami informacyjnymi, jakich dostarcza literatura fachowa czy obserwacja terenu zawodowego. Przydatność tych źródeł informacji dla planowanego przez studentów programu kursu okazuje się w równym stopniu ważna co nieistotna lub mało istotna.

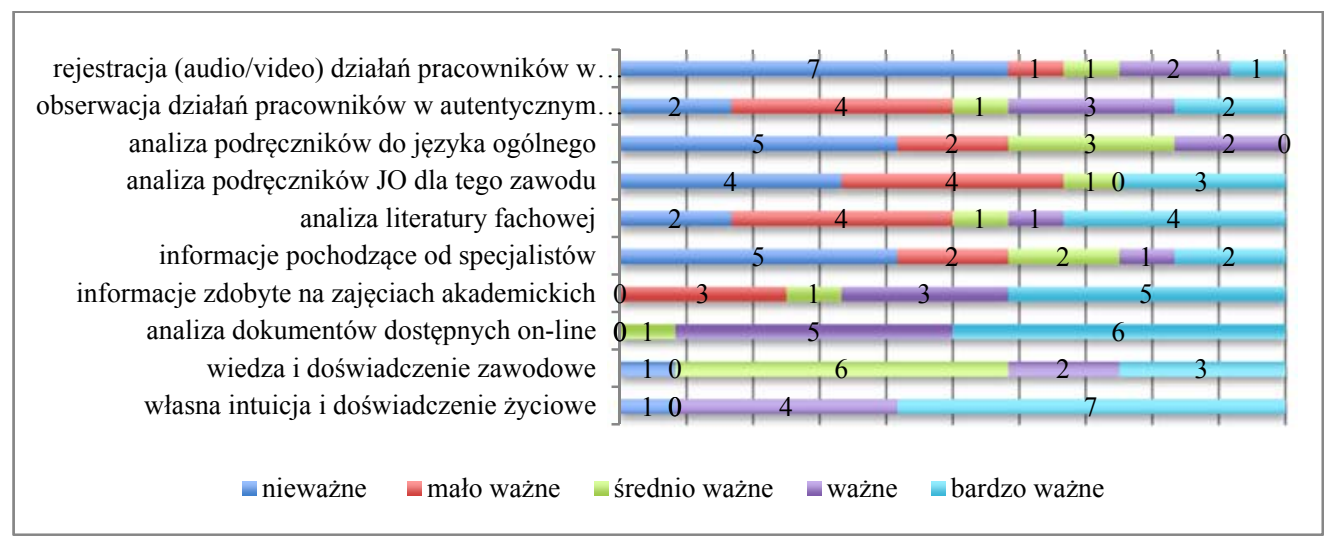

Wykres 3. Zasoby informacyjne wykorzystane do określenia celów ksztatcenia 


\subsubsection{Wybór dokumentów źródłowych}

Kontekst zawodowy właściwy dla wykonywanego zawodu czy zajmowanego stanowiska nie może obyć się bez dokumentów, których rola zmienia się w zależności od różnych parametrów. Natura tych dokumentów może być informacyjna, wyjaśniająca, opisowa, dyrektywna itp. Teksty i właściwe im dyskursy towarzyszą działaniom zawodowym, zaświadczają o wykonywanej aktywności czy służą jako dowód wykonanej pracy/ obowiązku. Dla twórców programów nauczania języka specjalistycznego, teksty autentyczne dostarczają najczęściej wskazówek na temat organizacji zajęć, selekcji treści nauczania, przygotowania materiałów nauczania i/ lub opracowania ćwiczeń, pozostając w zgodzie z logiką odnośnego zawodu/ stanowiska. Dlatego też jednym z zadań, jakie wykonać mieli studenci $\mathrm{w}$ trakcie opracowania zarysu programu kształcenia była selekcja materiałów autentycznych właściwych dla wybranego przez nich docelowego obszaru zawodowego. Także na tym etapie widać zdecydowaną predylekcję studentów do czerpania z własnej intuicji, zasobów internetowych czy notatek z zajęć. Zakres i stopień eksploatacji innych źródeł nie uległ znaczącej ewolucji w stosunku do poprzednich etapów, choć widać większe wykorzystanie własnych doświadczeń zawodowych, literatury fachowej czy obserwacji w terenie. Dywersyfikacja źródeł informacji na tym etapie wydaje się niezbędna. Intuicja i doświadczenie życiowe pozwalają z pewnością ,wyobrazić sobie" mniej lub bardziej poprawnie rodzaj wykonywanej pracy, ale nie są w stanie dokładnie określić natury dokumentów, jakimi dana osoba posługuje się (odbiera i tworzy) w trakcie wykonywanych obowiązków służbowych. Poza tym, im bardziej liczne i różnorodne są źródła informacji, tym bardziej pozwalają zminimalizować stopień subiektywności, jaką nasuwa intuicja.

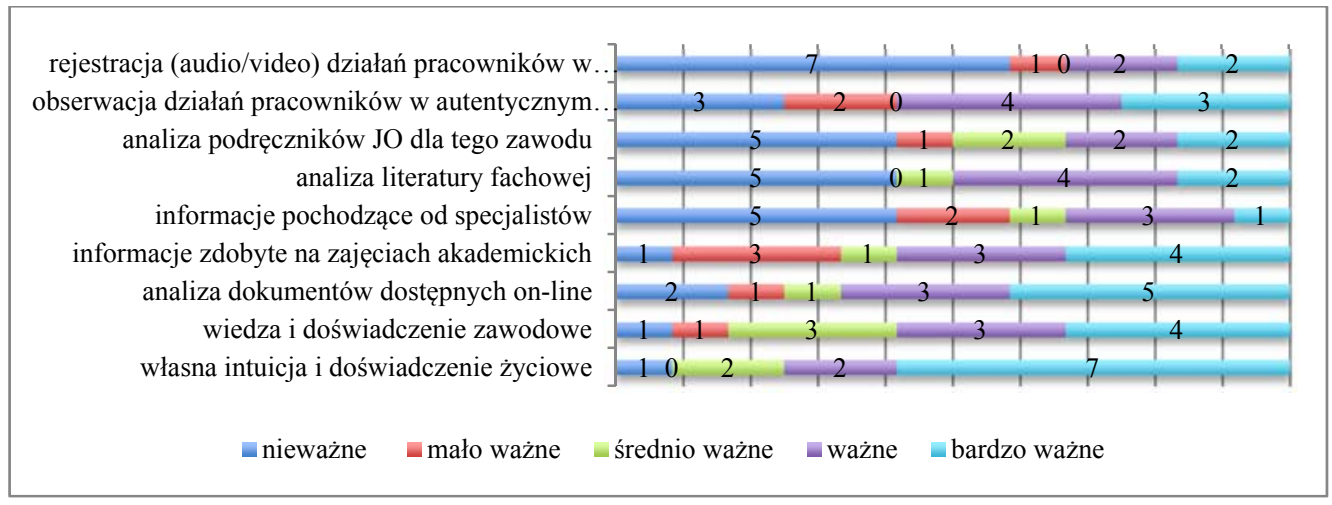

Wykres 4. Zasoby informacyjne wykorzystane do zdefiniowania dokumentów autentycznych

\subsubsection{Definiowanie aktów mowy}

Programowanie treści nauczania właściwych dla języka specjalistycznego wymaga zgłębiania informacji na temat sposobów formułowania wypowiedzi przez specjalistów/ pracowników w trakcie wykonywania obowiązków zawodowych. Biorąc pod 
uwagę fakt, że wysiłek nauczyciela języka specjalistycznego położony jest na opanowanie zasobów języka na użytek działań zawodowych wykonywanych za jego pomocą, bardzo ważne jest, aby dokładnie wiedział on, w jaki sposób oraz za pomocą jakich środków realizowane są wypowiedzi językowe w kontekście pracy, a co za tym idzie, jakie elementy języka włączyć do planowanego kształcenia. W celu zdobycia tego rodzaju informacji najbardziej właściwe wydają się obserwacja i rejestracja pracowników w trakcie ich pracy, które gwarantują najwyższą autentyczność i wiarygodność zebranego materiału językowego. Te źródła okazują się jednak marginalnie wykorzystywane przez studentów, pomimo relatywnie łatwego dostępu do obszaru zawodowego, jaki zadeklarowali na początku ankiety. Intuicja i Internet zajmują ciągle uprzywilejowane miejsce wśród źródeł informacji wskazanych przez studentów. Zanotować też należy lekki wzrost odpowiedzi w stosunku do własnego doświadczenia zawodowego i wywiadów z pracownikami. Niemniej jednak nieprawidłowości proponowanych sformułowan i błędy językowe w finalnych projektach studentów dowodzą, że ten etap pracy nie jest poparty wnikliwą i rzetelną analizą materiału językowego właściwego działaniom językowym realizowanym w miejscu pracy i będącym przedmiotem kształcenia.

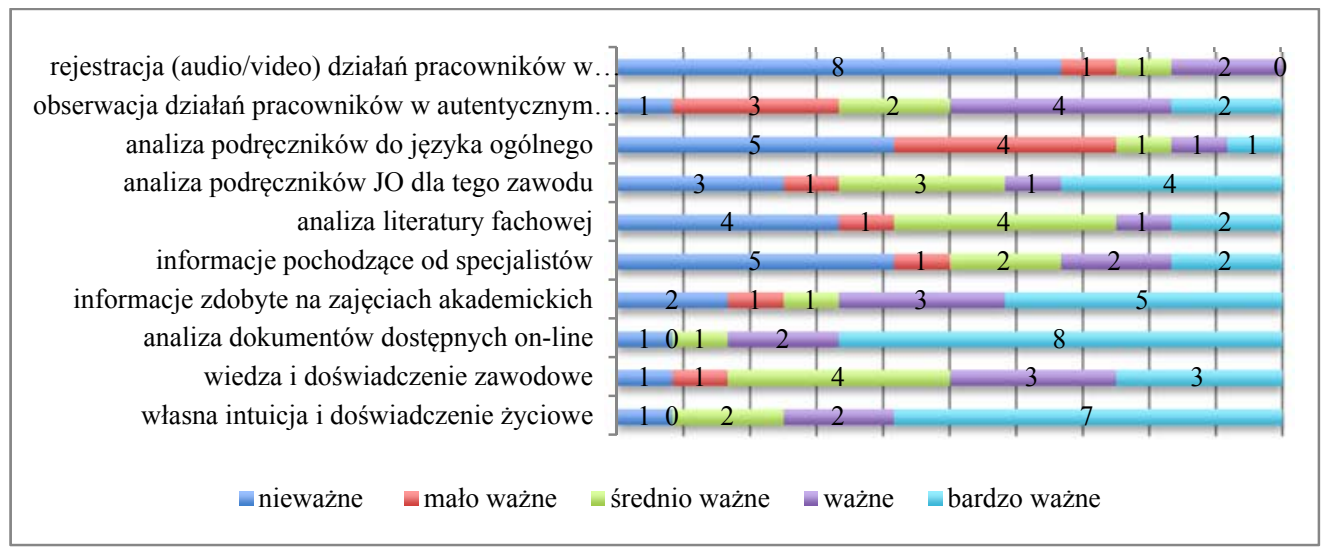

Wykres 5. Zasoby informacyjne wykorzystane do definicji aktów mowy

\section{Wnioski i rekomendacje}

Przeprowadzona wśród studentów ankieta samooceny ich działań planistycznych pokazuje, że wybory dydaktyczne studentów opierają się zasadniczo na źródłach informacji, wśród których uprzywilejowane miejsce zajmują intuicja, Internet i zajęcia uniwersyteckie. Studenci najrzadziej sięgają po informacje pochodzące od specjalistów z terenu uzyskane drogą wywiadów, obserwacji i/ lub nagrań. Dane pozyskane na temat planowanych elementów kształcenia w zakresie języka specjalistycznego można więc scharakteryzować jako intuicyjne i niepoparte weryfikacją we właściwym środowisku pracy. Są to także dane stosunkowo najłatwiej dostępne i pozostające w tzw. zasięgu ręki studentów (Internet, notatki z zajęć), bez konieczności opuszczania własnej „strefy komfortu”. Wreszcie są to informacje będące wynikiem su- 
biektywnych wyborów i arbitralnych decyzji studentów bez współpracy ze specjalistami znającymi kontekst zawodowy. Nasuwa się więc pytanie, jaka jest zatem realna użyteczność zgromadzonych informacji względem docelowego odbiorcy kształcenia i jego potrzeb. Czy studenci, jako przyszli nauczyciele-profesjonaliści, dołożyli wszelkich starań, aby dotrzeć do dostępnych sobie zasobów i wyeksploatować je w sposób pozwalający na wypracowanie rozwiązań stosownych do zidentyfikowanych problemów? Czy wykonali wszystko, co było konieczne dla rzetelnego przygotowania programu kształcenia i nie zaniedbali niczego istotnego? Zrealizowane przez nich programy nauczania języka specjalistycznego pozostawiają w tej kwestii dużo do życzenia i wiele mówią na temat informacyjnych kompetencji ich twórców.

Kontekst dydaktyczny, w jakim realizowana i oceniana była praca studentów, miał z pewnością szereg ograniczeń, takich jak m.in. krótki czasowy wymiar zajęć, praca wykonywana na ocenę jako zaliczenie zajęć, brak realnego powiązania programu z konkretną rzeczywistością edukacyjną. Niemniej jednak na podstawie opisanej powyżej analizy przypadku można zauważyć, że, planując kurs języka specjalistycznego, studenci nie postrzegają swojej roli i pracy odmiennie niż ma to miejsce w planowaniu kursu języka ogólnego. W większości przypadków powielają oni sposób pracy znany im i właściwy dla nauczyciela języka ogólnego, w którym nauczyciel jest od początku do końca specjalistą w zakresie języka, kultury i komunikacji, a który nie sprawdzi się w przypadku nauczyciela języka specjalistycznego, gdzie niezbędna jest ściślejsza współpraca ze specjalistami z terenu. Działania podjęte przez studentów na poszczególnych etapach planowania pokazują szereg niedostatków w ich kompetencji zawodowej, którą definiować należy znacznie szerzej niż w przypadku nauczycieli uczących języka ogólnego. Obserwacje przedstawione w ramach niniejszego tekstu, choć fragmentaryczne, skłaniają do postulowania, by podjąć szerzej zakrojone i bardziej zdecydowane działania mające na celu włączenie zajęć z dydaktyki języków dla potrzeb zawodowych do modułów przygotowania zawodowego nauczycieli języków obcych na polskich uczelniach.

\section{Bibliografia}

Basturkmen, H. (2014), LSP teacher education: review of literature and suggestions for the research agenda, (w:) „Ibérica” 28, 17-34.

Belcher, D. (2006), English for specific purposes: teaching to the perceived needs and imagined futures in worlds of work, study and everyday life, (w:) „TESOL Quarterly" 40, 133-156.

Dudley-Evans, T./ St. John, M. (1998), Developments in English for Specific Purposes. Cambridge.

Gajewska, E./ Sowa, M. (2014), LSP, FOS, Fachsprache... Dydaktyka języków specjalistycznych. Lublin.

Hall, D.R. (2013), Teacher education for languages for specific purposes, (w:) C.A. Chapelle (red.), Encyclopedia of Applied Linguistics. Oxford, 5537-5542.

Le Boterf, G. (2009), Construire les compétences individuelles et collectives. Paris. 
Lehmann, J.-C. (1996), De la gestion de la complexité à un corpus de 'sciences de l'action', (w :) J.-M. Barbier (red.), Savoirs théoriques et savoirs d'action. Paris, 147-159.

Mangiante, J.- M./ Parpette, C. (2004), Le Français sur Objectif Spécifique: de l'analyse des besoins à l'élaboration d'un cours. Paris.

Richer, J.-J. (2012), La didactique des langues interrogée par les compétences. Bruxelles. 